\title{
Is There A Role of Ovarian Ablation Using Radiotherapy in the Era of Precision Medicine?
}

\author{
Anusha M, Anuradha P, Praveen Kumar M and Lohith G* \\ Healthcare Global Enterprises limited, India
}

Submission: April 05, 2018; Published: May 07, 2018

"Correspondence Address: G Lohith, Consultant Radiation Oncologist, Chief Director-Radiomics and Radiogenomics, Healthcare Global Enterprises Limited, Bangalore, India, Email: lampard251185@gmail.com

\section{Editorial}

Management of Carcinoma breast has evolved over decades from Radical mastectomy to present day breast conservation surgeries and reconstructive surgeries, from 2D radiation therapy technique to present day IMRT/IGRT and Brachytherapy techniques, from toxic chemotherapy regimen to addition of taxanes and targeted therapy. Carcinoma breast is extensively studied to better the treatment options available and also to address the increasing incidence in young women. Ovarian Suppression did not take prime role in the management of cancer breast since it was mainly seen in perimenopausal who mostly attain amenorrhea after adjuvant chemotherapy and in postmenopausal women. Over the decades the incidence of carcinoma breast in young, premenopausal women has been on the rise owing to lifestyle changes, early detection by awareness programmes. Considering the changing population, the concept of ovarian suppression needs to be revisited and explored.

Considerable evidence proves the role of endogenous and exogenous hormones in the cancer breast with relative risk of 2 ; hence it is essential to attain low sustained estrogen levels even after definite treatment to achieve locoregional control of disease. Ovarian suppression can be attained by medications, surgical oopherectomy and radiation therapy. Analysis by NCIC CTG MA.5 in the early 2000s, clearly showed significant benefit of attaining amenorrhea in premenopausal women who received adjuvant chemotherapy in terms of Relapse Free Survival. Various articles have addressed the percentage of women attaining amenorrhea post CMF regime. Not with present day chemotherapy schedules including taxanes. Also, International trials evaluating medical OS-TEXT (Tamoxifen and Exemestane Trial) and SOFT (Suppression of Ovarian Function Trial) investigated adjuvant endocrine therapies for premenopausal women with hormone receptor- positive breast cancer, testing exemestane plus ovarian function suppression (OFS), tamoxifen plus OFS, and tamoxifen alone have observed improvement of $10 \%$ to $15 \%$ in 5 -year breast cancer free interval (BCFI) in women treated with medical Ovarian Suppression (OS). Zoladex in Premenopausal Patients trial has shown that the medical OS with goserelin for 2 years in premenopausal patients with ER-positive (ER+) disease produced a statistically significant benefit in terms of disease-free survival, PFS, and a trend toward improvement in OS, irrespective of concurrent adjuvant tamoxifen or chemotherapy.

Radiation therapy Ovarian Supression (RT-OS) and Surgical oophorectomy induced OS has similar efficacy as long term LHRHs. The Early Breast Cancer Trialists' Collaborative Group conducted meta-analysis of 12 randomized controlled trials (RCTs) comparing outcomes in premenopausal early breast cancer women who underwent oophorectomy or RT-OA compared with those receiving no adjuvant therapy. Relative reduction of recurrence was $12 \%$ in those who underwent either surgical or RT-OS.

Surgical OS is one-time procedure, but disadvantages are that it is invasive procedure with postoperative morbidity depending on surgery technique. RT-OS can be considered a reasonable alternative to long term LHRH or in those who are not candidates for LHRH analogs and in those not willing for invasive procedure. Advantages of RT-OS are that it is short term treatment, economical, manageable adverse effects, and non-invasiveness. Possible Second malignancy risk has not been addressed in any trials and potential risk is not completely known entirely. With the advent of newer Radiation techniques, adverse effects can be minimized. Assessment of ovarian movements by MRI pelvis possibly due to bowel filling is approximately $17.0 \pm 9.67 \mathrm{~mm}$ in the left ovary and $19.7 \pm 11.95 \mathrm{~mm}$ in the right ovary, which has to be considered while planning for RT-OS. 
This work is licensed under Creative Commons Attribution 4.0 License DOI: $10.19080 / C T O I J .2018 .10 .555791$

\section{Your next submission with Juniper Publishers} will reach you the below assets

- Quality Editorial service

- Swift Peer Review

- Reprints availability

- E-prints Service

- Manuscript Podcast for convenient understanding

- Global attainment for your research

- Manuscript accessibility in different formats

( Pdf, E-pub, Full Text, Audio)

- Unceasing customer service

Track the below URL for one-step submission https://juniperpublishers.com/online-submission.php 